\title{
The Arts Learning Model of BPK2 (Creative Work Practice Learning) Activities
}

\author{
Warih Handayaningrum $\bowtie$, Djoko Tutuko, Agus Suwahyono
}

\author{
Department of Arts, Drama, Dance and Music, Faculty Languages and Arts, \\ Universitas Negeri Surabaya, Indonesia
}

Received: March 7, 2019. Revised: May 17, 2019. Accepted: June 24, 2019

\begin{abstract}
The study program of Drama, Dance and Music Arts (Sendratasik) of FBS Unesa often gets visits from various schools in the city of Surabaya and surrounding areas for specific purposes, one of which is SMA Negeri 6. SMAN 6 Surabaya is one of the schools that organizes Creative Work Practice Learning (BPK2) at Sendratasik FBS Unesa. So that the implementation of BPK2 activities runs optimally, an appropriate learning model is needed. The purpose of this study is to describe the art learning model in BPK2 activities at SMA Negeri 6 Surabaya in Sendratasik FBS Unesa. The Qualitative approach was used in this study, the subjects are 306 students of SMA Negeri 6 Surabaya, 20 lecturers, and 20 students of FBS Unesa. The object of research, art learning models in Creative Work Practices Learning Activities (BPK2). Location in Sendratasik FBS Unesa. Data collection techniques: observation, interviews, documentation Data analysis is done during data collection, interactive with flexible techniques. Research results: Learning art with BPK2 activities use a humanistic approach that is optimizing the potential and interest of students in art. Art learning material includes appreciation and creation. Project-based models and apretensive models are used to produce works until they are performed. Staging learning outcomes as projects that must be completed by students are carried out well until BPK2 activities become meaningful learning because the benefits continue to be felt when returning to school. This research is important to encourage freedom of learning, so that art education according to its function gives rise to student creativity.
\end{abstract}

Keywords: art learning package, learning creative work practices, art learning model, free learning

How to Cite: Handayaningrum, W., Tutuko, D., \& Suwahyono, A. (2019). The Arts Learning Model of BPK2 (Creative Work Practice Learning) Activities. Harmonia: Journal of Arts Research And Education, 19(1), 62-70.

\section{INTRODUCTION}

Sendratasik FBS Unesa is often visited by school children, the community or institutions. School children who visit ranging from kindergarten, elementary, junior high or high school which mostly aims to appreciate more about art in the Sendratasik majors. But there are also those who aim to study dance or music that will be used for the purpose of overseas trips, and there are also those that aim to fill activities in the middle of the semester. Sukorejo State Junior High School Malang has visited Unesa's Sendratasik Department twice by bringing all of its students to appreciate dance and music. Another school that visited was Ciputra School which brought

\footnotetext{
${ }^{\square}$ Corresponding author:

E-mail: warihhandayaningrum@unesa.ac.id
} 
kindergarten and elementary students to appreciate in the arts. SMA Negeri 6 Surabaya recently also visited the Department of Sendratasik Unesa to organize Creative Work Practices Learning (BPK2) for three days.

The Department of FBS Sendratasik Unesa responds positively to schools that want to learn or appreciate whatever the goal is because this has a positive impact both for the Sendratasik department and for schools. These benefits include building synergy between the Sendratasik majors and schools, which can create fun learning. This is in accordance with the opinion of A.S Neil (in Pamadhi, 2012) that children's enjoyment will increase if they get a variety of learning materials with art and skills. Students will be motivated to study art because it matches their interests and talents. Learning motivation is an energy in humans that encourages learning activities with specific goals (Sani, 2016). This is in accordance with the policy of the minister of education Nadiem Makarim on Merde$k a$ Belajar, namely education that provides opportunities for both teachers and students to be free to think.

In addition, the Department of Sendratasik has the advantage of providing experience to students, namely tangible teaching experience that is relevant to the Learning Management Program to prepare students to become scholars of education who serve as teachers with professional skills and pedagogical competencies in terms of educating, teaching, guiding, directing, training and evaluating students (Tim LP3M, 2017) and the most important thing is that Unesa does not become a university that is far from the community and can bring in income for majors.

Vice Principal of Student Affairs at SMA Negeri 6 Surabaya said the impact of BPK2 SMA Negeri 6 Surabaya's activities carried out at Sendratasik FBS Unesa was extraordinary. Students get hands-on experience of enjoyable art practices, within 3 days they can perform on the stage for dance, music, theater, and cosmetology as a result of learning. As for students who are interested in learning staging management, are very enthusiastic and after returning to SMA Negeri 6 Surabaya, they lead the successful holding of school events (Utami interview, 10 January 2018).

So that the implementation of BPK2 activities runs optimally, it is necessary to prepare an appropriate learning method that can accommodate all learning materials that are only carried out with a duration of three days. Based on this background, the purpose of this research is to describe the art learning model for students of SMA Negeri 6 Surabaya at Sendratasik FBS Unesa.

\section{METHODS}

The research approach used is a qualitative research based on the philosophy of constructivism which assumes that reality is plural, interactive, and exchange of social experiences interpreted by individuals (Sukmadinata; Syaodih, 2013). This type of research is a case study that focuses on a phenomenon that wants to be understood in depth (Denzin, 2009) the phenomenon is a program of activities called Creative Learning Practices (BPK2).

The subjects of the study were students of SMA 6 Surabaya who took part in the midterm activities in Sendratasik FBS Unesa odd semester 2017/2018, namely class XI totaling 306 students, 25 accompanying teachers of SMA Negeri 6 Surabaya and 25 Lecturers of Sendratasik FBS Unesa 20 students of Sendratasik FB Unesa. The object of research is the management of art learning in Sendratasik for SMA Negeri 6 Surabaya. Research location at Sendratasik FBS Unesa. Data collection techniques using interviews carried out with, principals, students, and teacher assistants on several matters relating to BPK2 activities. Documentation related to archives and supporting libraries, observations were made to obtain data during BPK2 activities. done. Data analysis is performed during data collection, interactive with flexible techniques. 


\section{RESULTS AND DISCUSSION}

Based on research, this section will discuss the implementation of art learning, learning models used, and learning outcomes achieved from BPK2 activities.

Art Learning Implementation of SMA Negeri 6 Surabaya at Sendratasik FBS Unesa

306 students are grouped, given the freedom to choose classes according to their interests, so that when learning art arrives the child happily enters the room provided. Slameto (2010) states that interest is a feeling of preferability and a sense of attachment to a thing or activity, without anyone asking. Interest is basically the acceptance of a relationship between oneself and something outside of oneself. Slameto states that: interest is a feeling of preferability and a sense of attachment to a thing or activity, without anyone asking. Interest is basically the acceptance of a relationship between oneself and something outside of oneself. The stronger or closer the relationship, the greater the interest. The following are the results of class division according to students' interest in BPK2 activities.

Table 1. Distribution of Classes and Materials for the Performing Arts

$\begin{array}{ccc}\text { Groups } & \text { Field of Art } & \text { Number } \\ 1 & \begin{array}{c}\text { Traditional Makeup } \\ \text { and Clothing }\end{array} & 33 \\ & \text { Modern Dance and } & \\ 2 & \text { Makeup } & 33 \\ 3 & \text { Traditional dance } & 40 \\ 4 & \text { Non-Traditional Dance } & 39 \\ 5 & \text { Traditional Music } & 38 \\ 6 & \text { Non-Traditional Music } & 35 \\ 7 & \text { Music Illustration } & 38 \\ 8 & \text { Drama } & 31 \\ 9 & \text { Event Organizer } & 19 \\ \text { TOTAL } & & 306\end{array}$

According to Soehardjo (2011), learning of art is an activity, performance, or process that must be carried out. In art, les- sons include two major things, namely creation and appreciation. Creative activities are productive activities, and appreciation activities are responsive activities. In learning the art of creation and appreciation, it is functioned to get the follow-up results from their experience in the awareness of the art process, not to create students to become artists or art observers.

55-61The meaning of art education is the giving of aesthetic experience to students. Aesthetic experience is given through appreciation and creative/artistic creations, where in creative activities students are given the experience of creating/ reproducing, displaying art works (Masunah, 2003). Multicultural art education is a conscious effort to promote socio-cultural diversity through the provision of aesthetic experiences in the form of appreciation and artistic recreation/recreation activities. In creating creative works students can depart from the nearest environment, find their own methods, problems, develop self-expression/free to be creative.

55-61In the implementation of art education in the Sendratasik Department, each class is accompanied by two to three lecturers and 3 students. With the varied material mentioned in the table above, it is really a positive environment building because all students learn from each other with their friends. In the context of art education, humanism has a meaning as a system of thought, human interest and development become central and dominant, tends to glorify the culture and practice rather than scientific and speculative. In terminology, humanism is a theory that focuses on the problem of how each individual is influenced and guided by people they relate to their own experiences. The humanistic view that humans have a soul wealth that is loaded with potential to be developed (Firdaus, 2017). One of the teacher's tasks is to build interest and talent in a pleasant atmosphere, the teacher must be friendly, caring, tolerant and consistent. It is an important aspect of relationships with students. Using a seat map, to produce productive work. For music classes or 
dance seating maps can be perceived with maps of musical instruments (rhythmic, melodic or harmonious) or maps of certain dance styles (traditional, new, modern creations) according to students' interests.

55-61The principle of art learning in schools highlights its uniqueness and contribution specifically towards lifelong learning. Throughout schooling, students are expected to be involved in the practice of each branch of art and can reflect on experiences for the development of knowledge, skills (Sutedja, 2007). Ideally art learning has a positive impact on student competencies in real life in the school, home and community environment (Mudjiati, 2014). Learning art is an activity, performance, or process that must be carried out (Soehardjo, 2011). In art lessons include two major things, namely creation and appreciation. Creative activities are productive activities, and appreciation activities are responsive activities.

55-61The implementation of BPK2 activities uses a learning model, it is a conceptual framework in the form of a systemic procedure that is developed based on theory and is used in organizing teaching and learning processes to achieve learning goals (Sani, 2016). The stages of learning that students go through in BPK2 in Sendratasik FBS Unesa are as follows: (1) Each lecturer, who is responsible for his development class, provides motivation for the arts and inspiration for the preservation of local arts; (2) Students are given reading material that will be used, to enrich insight into the material being studied; (3) Students are shown learning procedures and mentoring; (4) Each group is given a project to be completed with their group; (5) Students present the results of their group work in the form of creative arts products; (6) make a report of the activities carried out; (7) The teacher monitors student activities in each class; (8) Providing assistance if there are technical problems in the field.

55-61According to (Trianto, 2007) the learning model above is project-based learning. Supporting learning theory in the project based learning model is social constructivism learning theory, developed by Lev Semenovich Vygotsky who argues that cognitive formation and development are formed through internalization/mastery of social processes. Students participate in social activities without purpose, then internalization or construction of new knowledge, and the transformation of knowledge through adult guidance (Eggen, Paul ; kauchak, 2004; Sani 2016).

The initial step is to gather and integrate new knowledge based on real experience. The operational steps are as follows: Determine fundamental questions, Design project planning, Arrange schedules, Monitor project activities and progress, Test results, Evaluate activities. The connectedness of the standard stages in art and subject matter of art learning according to (Soehardjo, 2011) is as follows: for creative art, the sequence of standard actions is sensing, imagery, media introduction and media processing. As for the art of appreciation, the introduction of media, sensing, imagery and media processing. In the art process the stages in the actual art activities cannot be clearly demonstrated the limits of the existence of sensing, imagery, media introduction and media processing because all is in inner actions. It functions as a framework for art learning strategies (Soehardjo, 2011).

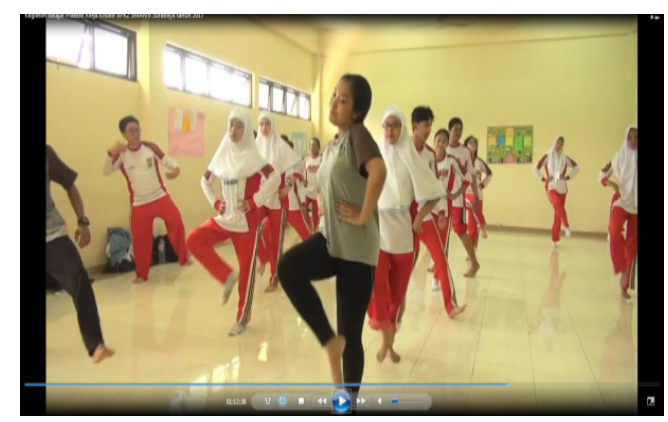

Figure 1. Student Creative Work Process in Dance (Doc. SMAN 6 Surabaya)

A number of dance learning methods are conducted by lecturers to provide experience to students of SMA Negeri 6 Surabaya, including the application of selected learning methods tailored to the 
implementation of the BPK2 program which is carried out for 3 consecutive days starting at 07.00 a.m- 3.30 p.m and every day is divided into 2 sessions namely: (1) the process of introducing teaching objects / materials (theoretical philosophy); and (2) the creative process of artistic work (practice) . In the first stage: the process of introducing teaching objects / materials (theoretical) is the earliest step taken in the implementation of dance learning which was carried out on April 18, 2017, the first session. The aim is to introduce the basic knowledge of dance.

On this initial occasion, two classes were held in an integrated manner in one room and alternated presentations. The technique used in learning by using audiovisual media that is, students are invited to observe video footage of dance forms as material to be studied. It is also supported by lecture methods to convey knowledge of the basics of dance movements, both traditional and non-traditional dance, especially those related to the material to be studied. Not enough with an introduction of material, instructors and technical staff also provide motivation for students to learn. Motivation is done in the form of a pleasant learning atmosphere, and when delivering material students also seem to be able to receive well. In accordance with the opinion, that with the motivation to learn that is poured to provide certain conditions so that children will and want to do.

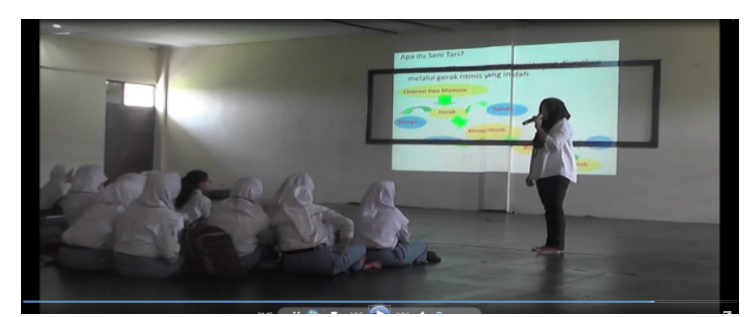

Figure 2. Non-Traditional Dance Learning

At this stage, students are given insights into dance and basic knowledge about arranging dance moves. When the learning process takes place students look very enthusiastic about paying attention to the instructor's explanation. Students also seemed motivated in responding to the material delivered by the instructor, and this was revealed in his enthusiasm in asking various questions to the instructor related to the discussion of the material.

Next is the second session, namely the creative process of artistic work (practice), which is the most core stage in dance learning activities. That is, in this activity is the introduction of dance forms material through the practice of direct gestures. Therefore, this creative process places more emphasis on students' psychomotor abilities. In this stage, the instructor conveys the material assisted by technical personnel who act as models. The dance model (technical staff) is carried out by students of Sendratasik Education Study Program who have the competence and technical skills of dance moves. With the assistance of technical staff (dance visuals), it is hoped that they can support the effectiveness and efficiency of delivering material to students.

Art education which is oriented towards art learning skills uses training. And the impact is the transmission of teacher skills to students. Such a model is called apprentice in line with behaviorism. The goal of the behavioristic theory is the formation of behaviors as learning outcomes that appear to be obtained by strict arrangement and reinforcement (Sani, 2016). The teacher transfers his skills to students, as a result the technique of one class is the same as what their teacher does. Duplicating learning methods are teaching methods that guide students to imitate existing forms of art or ready-made arts. Using the duplication method in learning is justified so that effective learning and copying are instinctive in human nature. Such learning is solely to achieve artistic skills in students, which does not encourage children's creativity.

Art skills are important in the learning process of art production. This art skill is then continued in the creative process of developing apperception and imaginative. If you stop at art skills, art edu- 
cation is the same as carpentry training (Soehardjo, 2011).

a. Creative Learning / Production Process

Media recognition (observing the model determined by the teacher)

Model sensing (trying to make shadows segmental)

Model immitating (following the teacher's instructions)

Media Processing $t \rightarrow$ ART WORKS

a. Art Learning Process Appreciation / Response

Media recognition (the object is determined by the teacher)

Object serfing (following the teacher's instructions)

Object immitating (following teacher pattern)

Media Prodessing

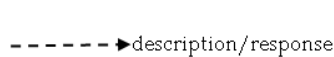

Figure 3. Art Learning Flow Map in the Aprentisip Learning Model

Figure of a flow map with the topic of production art for chart $A$ and chart $B$ is for the creation or response art. The topic is determined by the teacher before the learning process. Each process consists of four standard actions and two main actions of art production and art responsiveness (Soehardjo, 2011). It is also a model for 6 Surabaya high school students when participating in music activities.

\section{Progressive Model}

This model is also used in the learning of SMA N 6 Surabaya students. Art is the result of contemplating feelings of results that are supported by the aesthetic thoughts and experiences of students. Aesthetic experience is the performance of interactions between art actors/students and the aesthetic environment supported by sensing (Soehardjo, 2011). This progressive model is in line with constructivist learning and learning theories, where the learning process creates a learning climate that allows students to construct their own knowledge and skills. The learning of progressive art models is a feeling based model. This learning optimizes learning outcomes that prioritize the expression of feelings so that the learning outcomes are expressions. This learning depends on the substance expressed and how the performance takes place. The nature of the expression is personal, so the results are very personal and cannot be assumed to contain novelty. This is the expected learning outcome and is largely determined by the condition of the student and the technique of expressing his feelings. In education, there is certainly no absolute freedom which is often misunderstood. Freedom of learning still prioritizes its benefits.

The requirement for progressive learning is that students have sensing abilities. Students must be able to store the results of sensing in their own awareness. The results of sensing will produce shadows, imaginations, art ideas and responses in the form of feelings. So it becomes very important sensing education before applying a progressive model.

The structure of the progressive model of learning art is a set of procedural actions of teachers and students gradually. In a progressive model, the learning of the art of individual differences in students is an important concern. Who has finished the stage can go directly to the next stage, not having to wait for his friend to finish? This is deliberately given freedom by the teacher so that students are free to express their freedom in doing their work. The teacher's task is always to control the course of the learning process.

Freedom to behave in learning becomes a principle of progressive models. Teachers' perspectives and environmental conditions are subject choices by the teacher. Students who have a broad perspective will be the capital in completing their tasks and will be an obstacle for students with narrow sensing. Because sensing ability is the key to open the entire learning process of art.

The Figure 4 explains part $\mathrm{A}$ is a flow map of the learning process of art production and part B is a map of the flow of the responsiveness learning process. Learners work on assignments from the teacher individually. Topics and objects are determined by the teacher with various alter- 
natives and students choose themselves according to their sensing abilities. Sensing is done before the learning process takes place. Students after determining the topic and object, means students already have perceptions about imagery, about the media to be determined and process it after knowing the characteristics of the media. The final act is the realization of shadows through explorative or experimental actions. In response to art, the selected object is followed by sensing to determine the response (Soehardjo, 2011)

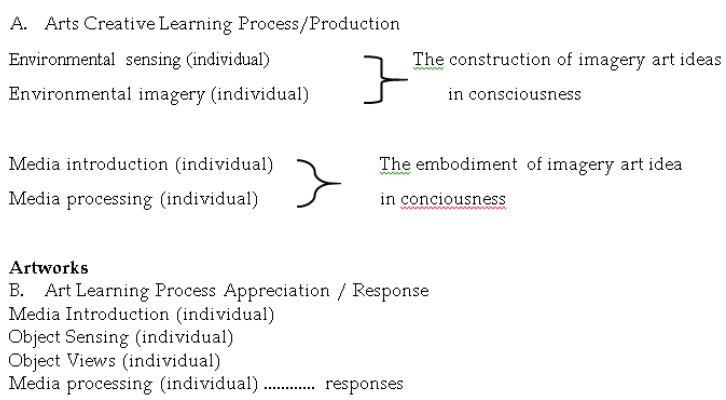

Figure 4. Arts Learning Flow Map in the Progressive Learning Model

\section{Standard stages in the Art Process}

Based on the opinion of Malcolm

Ross, the essence of the contents of the art curriculum contains four elements of art, namely sensing, imagery, media introduction, media processing. The four elements are explained as follows according to (Soehardjo, 2011).

\section{Sensing}

Sensing is an action within the framework of recognition. In sensing arts, for example seeing a mask with the sense of sight, listening to music with the sense of hearing, observing movements with the sense of sight and hearing. In art, sensing is only focused on forms that can be sensed and artistic. Through intense sensing sensory experience will emerge. Sensory experience in art will bring up creativity, give rise to artistic encouragement, build art ideas and contribute experiences for others. In appreciation, an atmosphere of feeling will give an artistic response and describe for others in order to contribute experiences. Sensing in the learning framework aims to foster aesthetic awareness. Sensing is the initial stage in learning arts. When students have sensed the process of sensory interaction occurs with the environment then enters the imaging process in the stage of imagery.

\section{Imagery}

The imagery process is realizing a certain form in wishful thinking. Not a dream but real. Imagery in the arts is a continuation of the process of sensing aesthetic objects in the process of observation that involves aesthetic attitudes. The results of imagery are to build art ideas, and aesthetic awareness. Both of these are as souls for the birth of art and as a means of expressing the meaning of artwork to be responded to. These two things really determine the process for its work.

\section{Media Introduction}

The introduction of the media is as a means to provide a manifestation of the senses of the shadows, imagination or art ideas that are in consciousness. The introduction of media in appreciation as a means to trigger an aesthetic response from observers. The introduction of media comes from the raw material of objects, sounds and certain movements for manifestation media to become art, music and dance. Students must recognize the characteristics of the embodiment media well. The experience of students getting to know the media is absolutely necessary. In its overall role the media as a means of embodiment of art in creative arts and a means of communication in the art of appreciation (Soehardjo, 2011).

\section{Media Processing}

Media processing is the function of raw materials and their characteristics to realize the idea of art in the form of inner works of art into works of art. In the process of creation, it involves awareness of reasoning, especially the sense of essence, which is functioned as a means to organize the elements of art in the framework of 
realizing the idea of art. In media processing creation is responding to the aesthetic objects through oral or written aesthetic response statements. Appreciation to build attention, provide responses through interpretation of images and imagination.

\section{Art Learning Outcomes of SMA Negeri 6 Surabaya students at Sendratasik FBS Unesa}

Students can master the material provided by each expert in the art they learn both appreciation and creation material. This can be seen on their last day showing the results of their learning in the headline, namely drama, dance and music as well as organizing students who participated in the event organizer. According to Ministry of Education and Culture Regulations no 104 in 2014 the objectives of the assessment are (1) Knowing the level of mastery of competencies; (2) Establish mastery of competency mastery; (3) Establish improvement or enrichment programs based on competency mastery levels; (4) Improve the learning process.

The students are very motivated to hold performances, because so far, many school activities are carried out, with learning experience from Sendratasik they know how to organize actual performances. Students get hands-on experience in art, which they don't get at school. His views on art have changed especially in traditional art. In the beginning, students choose to feel that their choices are outdated, but they don't want to stop practicing after feeling and enjoying them. This can be seen in traditional dance groups, traditional music. The process of learning good art is by experiencing empirically first, feeling how it feels then practicing it (Pamadhi, 2012b). Art learning conducted by lecturers invites children to experience learning Explained further in the Ministry of Education and Culture Regulations number 104 of 2014 Curriculum 2013 uses authentic and non-authentic assessments. An authentic assessment in question is an assessment of the attitudes, knowledge, and skills of the learning process to do the task in a real situation. In completing learning achievement the minimum level of attainment of attitudes, knowledge, and skills of students must be complete mastery of the substance and mastery of learning within the period of learning. An authentic assessment emphasizes the ability to learn to demonstrate the knowledge they have in a meaningful and tangible way (Nurgiyantoro, 2008).

According to Muller (Basuki, I, 2014), authentic assessment is defined as a form of assessment that requires students to perform real-world tasks that demonstrate meaningful applications of essential knowledge and skills. According to (Basuki, 2014) the nature of educational assessment according to authentic assessment is the process of collecting various data that can provide an overview of the development of student learning. This is important because the teacher will know the development of student learning. If the learning development of students does not match the objectives, the teacher will be able to take appropriate actions. The purpose of authentic assessment is to measure a variety of skills in various contexts that reflect the real situation in which the skills are used. An authentic assessment requires learners to demonstrate knowledge, skills, and products (Nurgiyantoro, 2008).

They also get discipline, cooperation, responsibility, for 3 days studying at Sendratasik FBS Unesa. They arrived on time, persevering and working together. In learning art, disciplined attitudes are embedded, respecting beauty, and responsibility. This awareness they get by realizing staging. Because the staging agenda will not become a reality if the players are not disciplined and serious.

Lecturers and students collaborate to serve learning appreciation and creation, this provides direct experience for students to prepare for practice at school. Providing space for lecturers for community service and research as well as research for students. From this activity, 3 PPM reports and 2 research reports have been produced. As a promotional event for Sendrata- 
sik at the School, students will be motivated and inspired according to their talents, and provide financial input to Sendratasik FBS

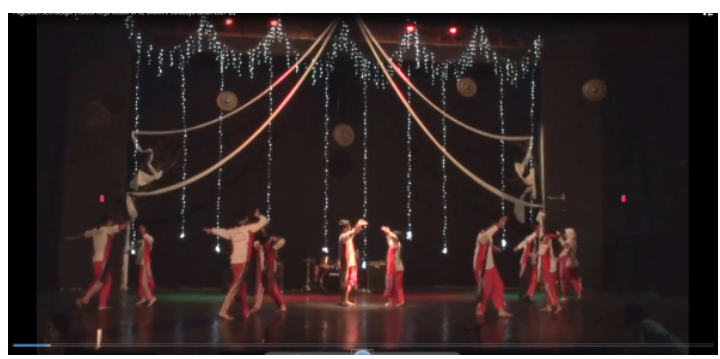

Figure 4. General Repetition of the atmosphere on stage at Sawunggaling Performance Hall (Foto: Septika Dwi N, 20 April 2017)

\section{CONCLUSION}

Universities such as Unesa with the formulation of the BLU policy, can manage various learning activities that can be sold. Sendratasik FBS Unesa as a work unit has developed businesses related to education. Businesses in the form of learning performance art can be packaged briefly and offered to schools, as a variety of activities outside of school to fill midterm activities.

Art education of school children in Sendratasik uses a project-based model, while using a short amount of time for 3 days. This model is effective in being able to produce performances for the whole field of art that students are interested in. Interest-based learning is able to create fun learning and encourage students to preserve their local culture.

The form of art education activities for school children in Sendratasik can be in the form of learning performance art in a short manner. This collaborative activity will enhance the Sendratasik role in schools and the community.

\section{REFERENCES}

Basuki,I, H. (2014). Assesmen Pembelajaran. Remaja Rosdakarya.
Denzin, N. K. \& Y. S. L. (2009). Handbook of Qualitative Research. Pustaka Pelajar.

Eggen, P. \& Kaushik, D. (2004). Educational Psychology. Prior.

Firdaus, F. A. (2017). Humanistic Approach In Education According to Paulo Freire. At-Ta'dib, 12(2). https:/ / doi.org/DOI: http:/ / dx.doi. org/10.21111/at-tadib.v12i2.1264

Masunah, J. (2003). Angklung di Jawa Barat Sebuah Perbandingan. Universitas Pendidikan Indonesia.

Mudjiati. (2014). Keunggulan dan kelemahan Kurikulum 2013 Mata Pelajaran Seni Budaya bidang Seni Rupa.

Nurgiyantoro, B. (2008). Penilaian Autentik. Cakrawala Pendidikan, 27(3), 250261.

Pamadhi, H. (2012a). Pendidikan Seni Hakekat Kurikulum Pendidikan Seni Habitus Seni dan pengajaran seni untuk Anak. UNY Press.

Pamadhi, H. (2012b). Pendidikan Seni Hakekat Kurikulum Pendidikan Seni Habitus Seni dan pengajaran seni untuk Anak. UNY Press.

Sani, R. A. (2016). Inovasi Pembelajaran. Bumi Aksara.

Slameto, S. (2010). Belajar dan Faktor-faktor yang Mempengaruhinya. Rineka Cipta.

Soehardjo, A. . (2011). Pendidikan Seni. P3T Ikip Malang.

Sukmadinata, Syaodih, N. (2013). Metode Penelitian Pendidikan. PT Remaja Rosdakarya.

Sutedja, W. (2007). Panduan Layanan Konsumen. PT. Grasindo, Anggota IKAPI.

Tim LP3M. (2017). Buku Pedoman Program Pengelolaan Pembelajaran. Unesa.

Trianto. (2007). Model-model pembelajaran Inovatif berorientasi Konstruktivistik. Prestasi Pustaka. 